\title{
The occurrence of Ambrosia pollen in Rzeszów, Kraków and Poznań, Poland: investigation of trends and possible transport of Ambrosia pollen from Ukraine
}

\author{
Idalia Kasprzyk • Dorota Myszkowska • \\ Lukasz Grewling • Alicja Stach • Branko Šikoparija • \\ Carsten Ambelas Skjøth • Matt Smith
}

Received: 21 June 2010/Revised: 27 September 2010 /Accepted: 27 September 2010/Published online: 30 October 2010

(C) The Author(s) 2010. This article is published with open access at Springerlink.com

\begin{abstract}
Previous studies have shown that ragweed pollen arrives in Poland from sources in the south, in Slovakia, the Czech Republic, Hungary and Austria. It is likely that ragweed pollen also arrives from sources in the southeast (e.g. Ukraine). This hypothesis was investigated using 13 years of pollen data and back-trajectory analysis. Ambrosia pollen data were collected at three sites in
\end{abstract}

I. Kasprzyk $(\bowtie)$

Department of Environmental Biology, University of Rzeszów, Rejtana 16c,

Rzeszów 35-959, Poland

e-mail: idalia@univ.rzeszow.pl

D. Myszkowska

Department of Clinical and Environmental Allergology,

Jagiellonian University, Medical College,

Śniadeckich 10,

Kraków 31-531, Poland

Ł. Grewling $\cdot$ A. Stach

Laboratory of Aeropalynology, Adam Mickiewicz University,

Umultowska 89,

Poznań 61-614, Poland

\section{B. Šikoparija}

Department of Biology and Ecology, Laboratory for Palynology, University of Novi Sad,

Trg Dositeja Obradovica 2,

Novi Sad 21000, Serbia

C. Ambelas Skjøth

Department of Atmospheric Environment,

National Environmental Research Institute, University of Aarhus, Frederiksborgvej 399, P.O. Box 358, Roskilde 4000, Denmark

\section{Smith}

National Pollen and Aerobiology Research Unit,

University of Worcester,

Worcester WR2 6AJ, UK
Poland, Rzeszów, Kraków and Poznań. The amount of ragweed pollen recorded at Rzeszów was significantly higher than in Poznań and Kraków. This can be related to either a higher abundance of local populations of Ambrosia in south-east Poland or the proximity of Rzeszów to foreign sources of ragweed pollen. The combined results of pollen measurements and air mass trajectory calculations identified plumes of Ambrosia pollen that were recorded at Rzeszów, Kraków and Poznań on 4 and 5 September 1999 and 3 September 2002. These plumes arrived at the pollenmonitoring sites from an easterly direction, indicating sources of Ambrosia pollen in eastern Poland or Ukraine. This identifies Ukraine as a possible new source of ragweed pollen for Poland and therefore an important source area of Ambrosia pollen on the European Continent.

Keywords Aerobiology $\cdot$ Ragweed $\cdot$ Allergy $\cdot$ Invasive species $\cdot$ Back-trajectory analysis

\section{Introduction}

The pollen grains of Ambrosia spp. (ragweed) contain very potent allergens that are known to cross-react with the allergens of Artemisia (Asero et al. 2006) - another member of the Asteraceae family. The threshold values provoking allergy symptoms differ in different countries. The threshold value is below 20 Ambrosia pollen grains per cubic metre in Austria (Jäger 2000), 13 pollen grains in France (Laaidi and Laaidi 1999), and 30 (Makra et al. 2005) or 50 (Juhász and Gallowich 1995) pollen grains in Hungary. In the United States, over $26 \%$ of the population is sensitive to Ambrosia pollen. In Europe, sensitisation is still increasing (Jäger 2000; Rybníček et al. 2000; Yankova et al. 2000; 
Vitányi et al. 2003; Chrenová et al. 2009). In Hungary-one of the most ragweed-contaminated countries in Europeapproximately $60 \%$ of pollinosis sufferers are sensitive to Ambrosia pollen (Vitányi et al. 2003; Makra et al. 2005).

The genus Ambrosia contains about 40 species and several subspecies. Only one species, A. maritima L., is native to Europe (Vitányi et al. 2003; Taramaracaz et al. 2005). Other species found in Europe were introduced from the New World. The most frequently noted of these is $A$. artemisiifolia L. (= Ambrosia elatior L.) (short or common ragweed). Less common are A. trifida L. (=A. aptera DC.) (giant ragweed), A. psilostachya DC. (= A. coronopifolia Torr. \& Gray) (perennial ragweed) and A. tenuifolia Spreng. (silver ragweed) (Laaidi and Laaidi 1999; Stępalska et al. 2002; Makra et al. 2005; Taramaracaz et al. 2005). The first records of $A$. artemisiifolia in Europe were in Croatia and Montenegro in the first half of the nineteenth century (de Visiani 1842). The plant was probably imported to Europe in ballast or seed lots. The distribution of ragweed increased after the First World War, but it was not considered invasive until the middle of the twentieth century. It favours sites of human activity and grows in ruderal habitats, along roads, railway embankments and fallow land. It is a noxious weed in agriculture (Vitányi et al. 2003).

In Europe, three main centres are infected by ragweed: (1) The Carpathian Basin/Pannonian Plain, primarily Hungary (Járai-Komlódi 2000; Juhász et al. 2004) but also parts of eastern Austria (Jäger 2000), Croatia (Juhász et al. 2004; Peternel et al. 2005), the Czech Republic (Rybníček et al. 2000), Romania (Juhász et al. 2004), Serbia (Juhász et al. 2004; Šikoparija et al. 2006), Slovakia (Makovcová et al. 1998), Slovenia (Juhász et al. 2004) and Ukraine (Mosyakin and Yavorska 2002); (2) the Rhône-Alpes region of France (Laaidi and Laaidi 1999; Laaidi et al. 2003); (3) Northern Italy, especially the northwest regions of Piedmont and Lombardy and the northeast regions of Veneto and FriuliVenezia Giulia in northern Italy (Peternel et al. 2005; Cecchi et al. 2006). Ambrosia is expanding its distribution and has recently been noted in Germany (Brandes and Nietzsche 2006), Switzerland (Taramaracaz et al. 2005) and Poland (Stach et al. 2007; Stępalska et al. 2008).

Ragweed favours a warm continental climate, and dry, rich soils with neutral or slightly acid pH (Dahl et al. 1999; Stępalska et al. 2002; Peternel et al. 2005; Taramaracaz et al. 2005). Ragweed does not favour a cool maritime climate with high relative humidity (Comtois 1998; Dahl et al. 1999; Saar et al. 2000). Photoperiod and temperature are factors that determine the distribution of Ambrosia. It is a short-day plant and flowering starts in autumn. The average September temperature is the main parameter determining distribution (Reznik 2009). The northern limit of its range is near $50^{\circ} \mathrm{N}$, and temperature also controls altitudinal distribution (Allard 1945; Genton et al. 2005). As a result, Ambrosia is recorded only occasionally in northern European countries such as Sweden, and its pollen has yet to present a serious allergological problem (Dahl et al. 1999; Saar et al. 2000). In warmer southern Europe (Spain and southern Italy), the climate is unfavourable to short ragweed and giant ragweed because of long hot, dry summers involving excessive desiccation of air and soil (Allard 1945).

Ambrosia artemisiifolia, A. psilostachya and A. trifida have all been recorded in the flora of Poland. The former two taxa have the status of naturalised species, while $A$. trifida is regarded as sporadically introduced. A. artemisiifolia is most frequently noted (Chłopek and Tokarska-Guzik 2006). Ragweed has not been recorded at any sites in the flora of Rzeszów and its close vicinity. The three nearest (documented) sites of $A$. artemisiifolia were observed about $70 \mathrm{~km}$ east of Rzeszów-close to the border with Ukraine. One population occupies uncultivated land; the other two inhabit railway tracks (Tokarska-Guzik 2001; Nobis and Nobis 2006). In Kraków, several Ambrosia stands have been recorded near railway stations Płaszów and Bieżanów (Tokarska-Guzik 2001). A. artemisiifolia has been recorded in Poznań (Poland) in the past (Żukowski 1960; Jackowiak 1993) but recent surveys have shown that these areas are no longer populated (Stach 2006).

Airborne ragweed pollen is frequently noted at all the aerobiological monitoring sites in Poland, but it is recorded only intermittently and concentrations are generally low. The highest annual totals of airborne Ambrosia pollen grains have been recorded in southern (Sosnowiec) and south-eastern (Lublin, Rzeszów) parts of the country (Chłopek and Dąbrowska 2006; Piotrowska and Weryszko-Chmielewska 2006).

Ragweed produces large quantities of pollen grains that are small $(18-22 \mu \mathrm{m})$ and suitable for long-range transport (Dahl et al. 1999; Saar et al. 2000; Taramaracaz et al. 2005; Cecchi et al. 2006; Fumanal et al. 2007). Due to the limited distribution of Ambrosia in Poland it was assumed that the pollen of this plant recorded in the air of Poland originates primarily from allochthonous sources. Previous studies have shown that ragweed pollen arrives in Poland from sources in the south, in Slovakia, the Czech Republic, Hungary and Austria (Stach et al. 2007; Smith et al. 2008). It is likely that ragweed pollen arrives from other source regions such as Ukraine as suggested by previous authors (Steppalska et al. 2002). Ukraine contains large regions with climatic conditions that favour ragweed growth and as a result can potentially be an important source area of ragweed pollen for Europe via long-range transport to other regions such as Poland. The present study investigated this hypothesis using 13 years of pollen data from Poland and back-trajectory analysis. 


\section{Materials and methods}

Ambrosia pollen data

Ambrosia pollen data were collected at three sites in Poland (Table 1) from 1997 to 2009 using volumetric spore traps of the Hirst design (Hirst 1952). Air is sucked into the trap at a rate of $10 \mathrm{l} / \mathrm{min}$ through a $2 \mathrm{~mm} \times 14 \mathrm{~mm}$ orifice. Behind the orifice, the air flows over a rotating drum (or microscope slide) that moves past the inlet at $2 \mathrm{~mm} / \mathrm{h}$ and is covered with an adhesive coated, transparent plastic tape. Particles in the air impact on the tape, yielding timestamped samples (Emberlin 2000). Following its removal from the trap, the tape is divided into segments corresponding to $24 \mathrm{~h}$ periods (48 $\mathrm{mm}$ in length) (Piotrowska and Weryszko-Chmielewska 2006). Each segment is mounted between a glass slide and cover slip using a mixture that usually contains gelatine, glycerine, phenol, distilled water and basic fuchsine (Laaidi et al. 2003). The samples are then examined by light microscopy. Two different counting methods were employed in this study: (1) in Rzeszów (1997-2009) and Poznań (19971999) a method similar to that described by Stach (2000) was used, whereby pollen grains were counted along 12 latitudinal transects, each corresponding to a 2-h interval (Kasprzyk 2008); (2) in Kraków (1997-2009) and Poznań (2000-2009) a technique similar to the method described by the Spanish Aerobiological Network (REA; Galán et al. 2007) was used, where slides were examined along 4 longitudinal transects divided into $2 \mathrm{~mm}$ intervals $(2 \mathrm{~mm}=$ $1 \mathrm{~h})$. It should be noted that Ambrosia pollen data from 2007 and 2008 in Rzeszów were not available for analysis. The use of two different counting methods meant that it was necessary to transform hourly counts into 2-hourly counts so that a direct comparison could be made between sites. Daily average (0000 to 2400 hours) Ambrosia pollen counts and diurnal variations (2-h counts) are expressed as grains $/ \mathrm{m}^{3}$.

\section{Climate}

Poland is characterised by a Continental climate. Rzeszów and Kraków are situated in the Upper Vistula Basin-a temperate dry region. According to Niedźwiedź (1981,
2004) and Niedźwiedź and Obrębska-Starklowa (1991), transformed polar-maritime air masses influence weather in this region. Winds are mainly from the west (SW, W and NW). Poznań is also located in an area of western circulation and, as a result, winds from the West and southwest predominate.

In Rzeszów, mean January and July temperature are $-2.1^{\circ} \mathrm{C}$ and $19.1^{\circ} \mathrm{C}$ respectively, and annual precipitation is $712 \mathrm{~mm}$ (mean data for 1997-2005). In the Rzeszów region, maximum and minimum precipitation occurs in July (mean $80 \mathrm{~mm}$ ) and February (mean $27-50 \mathrm{~mm}$ ), respectively (Brzeźniak 2007).

In Kraków, the mean January and July temperature are $-2.5^{\circ} \mathrm{C}$ and $18.2^{\circ} \mathrm{C}$, respectively, and the annual precipitation ranges from 700 to $750 \mathrm{~mm}$ (Niedźwiedź and Obrębska-Starklowa 1991; Matuszko 2007). Mean January and July temperatures in Poznań are $-1.4^{\circ} \mathrm{C}$ and $19.2^{\circ} \mathrm{C}$, respectively, and mean annual precipitation is approximately 500 mm (Woś 1994; Stach 2000).

\section{Statistical analysis}

Statistical analyses were performed on daily average Ambrosia pollen counts recorded in three periods during 1997-2009: (1) 1 August-30 September [VIII-IX]; (2) 1 August-15 October [VIII-15.X]; (3) 1 August-31 October [VII-X]. The period [VIII-IX] was selected because in Poland the maximum Ambrosia pollen concentrations are recorded in August and September (Kasprzyk 2008; Stępalska et al. 2008). However, Ambrosia pollen grains can also be observed from August to the first half of October [VIII-15.X] or for longer periods from July until the end of October [VII-X]. A screening test was used to select the statistical methods used in this paper. The screening test used was the Shapiro-Wilk (SW) test for normality. The SW test shows that the pollen data were not distributed normally and so non-parametric statistics were used. Variations in daily average Ambrosia pollen concentrations and seasonal pollen index (SPI) values in Rzeszów, Kraków and Poznań were identified using Friedman test and Nemenyi's procedure (multiple pairwise comparisons involving $K$ group means). Taking into account the fact that there are $\mathrm{k}(\mathrm{k}-1) / 2$ possible comparisons, the correction of the significance level proposed by Bonferroni was applied
Table 1 Pollen-monitoring sites used in this study

\begin{tabular}{llllllll}
\hline Site & Latitude & Longitude & $\begin{array}{l}\text { Height above } \\
\text { sea level }(\mathrm{m})\end{array}$ & $\begin{array}{l}\text { Height of trap above } \\
\text { ground level }(\mathrm{m})\end{array}$ & $\begin{array}{l}\text { Number of years } \\
\text { in study }(n)\end{array}$ \\
\hline Poznań & $52^{\circ}$ & $24^{\prime} \mathrm{N}$ & $16^{\circ}$ & $53^{\prime} \mathrm{E}$ & 86 & 33 & 13 \\
Kraków & $50^{\circ}$ & $04^{\prime} \mathrm{N}$ & $19^{\circ}$ & $58^{\prime} \mathrm{E}$ & 206 & 20 & 13 \\
Rzeszów & $50^{\circ}$ & $01^{\prime} \mathrm{N}$ & $22^{\circ}$ & $02^{\prime} \mathrm{E}$ & 202 & 12 & 11 \\
\hline
\end{tabular}


(XLSTAT 2010). The relationship between daily average ragweed pollen counts recorded at the different stations was investigated using Spearman's rank non-parametric correlation analysis. The hypothesis was tested with $P<0.05$, 0.01 and 0.001. Simple linear regression analysis was carried out in order to investigate trends over time. The following statistics are presented: the slope of the regression, standard error of the slope (SE), coefficient of determination $\left(R^{2}\right)$ and the probability level $(P)$. The calculations were carried out using statistical software packages the STATISTICA program version 8.0 and XLSTAT (2010).

\section{Back-trajectory analysis}

Back-trajectories indicate possible source areas and were calculated at the National Environmental Research Institute (NERI) in Denmark, following the methodology described by Stach et al. (2007). The back-trajectories were run at 6-hourly intervals throughout the study periods. Each back-trajectory was run for 4 days with 6-hourly steps. All times are presented as Central European Summer Time (UTC + 2).

Ambrosia pollen episodes tested for long-distance transport

The rationale for selecting episodes for further investigating using back-trajectory analysis is based on the work by Bianchi et al. (1959) and Ogden et al. (1969). The authors described how Ambrosia pollen form a local source peak in the morning (between about 0630 hours and midday). On the other hand, Ambrosia pollen recorded at night or in the early morning, before the local plants commence flowering, suggests that these pollen grains were released the previous day (or preceding days) and arrived via long-range transport. Such peaks in concentrations recorded in the night or early morning may be related to night-time cooling, which would deposit pollen grains that had been kept airborne during the day by convection (Faegri and Iversen 1992). This justification for selecting episodes for analysis was based on previous work by the authors, which have shown how back-trajectories in combination with measured pollen concentrations can be used to track plumes of Ambrosia that progress from source areas into countries such as Poland (Smith et al. 2008) or Macedonia (Šikoparija et al. 2009). Taking into account this description of Ambrosia pollen release, two ragweed pollen episodes were chosen for analysis. These episodes identified using the results of statistical analysis carried out on daily average and annual Ambrosia pollen counts were characterised by unusually high daily average ragweed pollen concentrations and Ambrosia pollen recorded at night or in the early morning.

\section{Results}

Analysis of pollen seasons

\section{Annual totals and daily pollen counts}

Annual sums of Ambrosia pollen grains (SPI) varied considerably between the three sites. The highest daily counts were recorded in 1999 and occurred almost on the same day (3, 4 and 5 September 1999) in Kraków, Rzeszów and Poznań, respectively. The years 1999, 2002 and 2005 also recorded daily average Ambrosia pollen counts $>20$ grains $/ \mathrm{m}^{3}$ at all three sites (Table 2).

Spearman correlation analysis carried out on daily average Ambrosia pollen counts recorded in three periods during 1997-2009 (Table 3) shows that the strongest relationship between the daily Ambrosia pollen counts recorded at all three sites (Rzeszów, Kraków and Poznań) occurred in 1999, 2002 and 2005. The strongest synchronization in pollen seasons was between Rzeszów and Kraków in 2002. Relationships between pollen seasons were weakest for the period of August-October [VII-X], and were often not statistically significant (Table 3).

There were significant differences in the magnitude of daily average Ambrosia pollen counts recorded at these three sites during the three years mentioned (Table 4). Comparison of annual totals of ragweed pollen using the Friedman test showed that the SPI recorded at three sites differed significantly $(P<0.05$, data not shown). The Nemenyis procedure also revealed significant differences $(P<0.05)$ between the SPI noted at Rzeszów and the SPI recorded at Kraków and Poznań, but not between the SPI at Kraków and Poznań (Table 5). The highest Ambrosia SPI was recorded at Rzeszów and the lowest number of Ambrosia pollen grains recorded annually was at Poznań (Table 6). The number of days when the ragweed pollen counts exceeded 20 grains $/ \mathrm{m}^{3}$ was also highest in Rzeszów (Table 2).

\section{Trends in total yearly sum}

No significant trends were found in the amount of Ambrosia pollen recorded annually at Rzeszów, Poznań and Kraków during 1997-2009. However, in Kraków a slight upward trend was recorded and opposite tendencies were described in Poznań and Rzeszów (Table 6).

Back-trajectory analysis on 4 and 5 September 1999

Distinct peaks in daily Ambrosia pollen concentrations occurred at Rzeszów, Kraków and Poznań on 4 and 5 September 1999 (Table 7). Several fronts were located over the study area on 1 September, which were replaced by 
Table 2 Maximum daily Ambrosia pollen concentrations (grains $/ \mathrm{m}^{3}$ ), day of maximum daily pollen concentrations (day from 1 January) and number of days with concentrations above 20 pollen grains $/ \mathrm{m}^{3}$ recorded in Rzeszów, Kraków and Poznań during 1997-2009. CV Coefficient of variation

\begin{tabular}{|c|c|c|c|c|c|c|c|c|c|}
\hline \multirow[t]{2}{*}{ Year } & \multicolumn{3}{|c|}{$\begin{array}{l}\text { Maximum daily pollen } \\
\text { concentrations (grains } / \mathrm{m}^{3} \text { ) }\end{array}$} & \multicolumn{3}{|c|}{$\begin{array}{l}\text { Day of maximum daily average Ambrosia } \\
\text { pollen concentration (day from } 1 \text { January) }\end{array}$} & \multicolumn{3}{|c|}{$\begin{array}{l}\text { Number of days }>20 \text { Ambrosia } \\
\text { pollen grains } / \mathrm{m}^{3} \text { daily average }\end{array}$} \\
\hline & Rzeszów & Kraków & Poznań & Rzeszów & Kraków & Poznań & Rzeszów & Kraków & Poznań \\
\hline 1997 & 34 & 6 & 44 & 235 & 237 & 238 & 2 & 0 & 3 \\
\hline 1998 & 125 & 47 & 12 & 253 & 255 & 249 & 4 & 1 & 0 \\
\hline 1999 & 319 & 85 & 109 & 247 & 246 & 248 & 6 & 5 & 4 \\
\hline 2000 & 86 & 14 & 12 & 234 & 232 & 241 & 7 & 0 & 0 \\
\hline 2001 & 98 & 34 & 41 & 247 & 229 & 243 & 2 & 1 & 1 \\
\hline 2002 & 98 & 39 & 92 & 248 & 247 & 240 & 6 & 1 & 4 \\
\hline 2003 & 55 & 23 & 9 & 255 & 241 & 241 & 5 & 1 & 0 \\
\hline 2004 & 42 & 31 & 6 & 243 & 243 & 255 & 3 & 1 & 0 \\
\hline 2005 & 59 & 29 & 53 & 253 & 237 & 250 & 5 & 1 & 3 \\
\hline 2006 & 64 & 14 & 51 & 237 & 268 & 257 & 3 & 0 & 4 \\
\hline 2007 & & 21 & 48 & & 234 & 234 & & 1 & 1 \\
\hline 2008 & & 70 & 22 & & 249 & 245 & & 7 & 1 \\
\hline 2009 & 98 & 50 & 16 & 246 & 253 & 253 & 4 & 3 & 0 \\
\hline Mean & 98.0 & 35.6 & 39.6 & 245.3 & 243.9 & 245.7 & 4.3 & 1.7 & 1.6 \\
\hline $\mathrm{SD}$ & 78.4 & 22.8 & 32.2 & 7.3 & 10.8 & 7.0 & 1.7 & 2.1 & 1.7 \\
\hline $\mathrm{CV}(\%)$ & 80.0 & 63.9 & 81.2 & 3.0 & 4.4 & 2.8 & 39.3 & 123.9 & 105.8 \\
\hline
\end{tabular}

high pressure over Northern Germany $(\sim 1,025 \mathrm{hPa})$ on 2 September. During this period, the approaching air masses gradually veered from the Northwest to the East. Daily average Ambrosia pollen counts $>20$ grains $/ \mathrm{m}^{3}$ were recorded at Rzeszów and Kraków from 3 to 7 September, at Poznań from 4 to 6 September. This corresponded to a period when an area of high-pressure in the region of 1,033-1,030 hPa remained over European Russia, and low-pressure centres were located to the north of the British Isles and Scandinavia. The air masses continued to veer

Table 3 Spearman correlation coefficients between daily average Ambrosia pollen concentrations recorded in Rzeszów. Kraków and Poznań in three periods during 1997-2009: (1) 1 August-30 September [VIII-IX]; (2) 1 August-15 October [VIII-15.X]; (3) 1 August-31 October [VIII-X];

\begin{tabular}{|c|c|c|c|c|c|c|c|c|c|}
\hline \multirow[t]{2}{*}{ Year } & \multicolumn{3}{|c|}{ Rzeszów-Kraków } & \multicolumn{3}{|c|}{ Kraków-Poznań } & \multicolumn{3}{|c|}{ Rzeszów-Poznań } \\
\hline & VIII-IX & VIII-15.X & VIII-X & VIII-IX & VIII-15.X & VIII-X & VIII-IX & VIII-15.X & VIII-X \\
\hline 1997 & $0.278 *$ & $0.290 * *$ & $0.279 *$ & $0.243 *$ & $0.281 * *$ & NS & $0.431 * * *$ & $0.424 * * *$ & $0.435 * * *$ \\
\hline 1998 & $0.384 * * *$ & $0.409 * * *$ & $0.335 * *$ & $0.542 * * *$ & $0.544 * * *$ & $0.537 * * *$ & $0.428 * * *$ & $0.441 * * *$ & $0.396^{* *}$ \\
\hline 1999 & $0.427 * * *$ & $0.433 * * *$ & $0.437 * * *$ & $0.580 * * *$ & $0.583 * * *$ & $0.593 * * *$ & $0.484 * * *$ & $0.495 * * *$ & $0.501 * * *$ \\
\hline 2000 & $0.317 * *$ & $0.344 * * *$ & $0.364 * *$ & NS & NS & NS & NS & NS & NS \\
\hline 2001 & $0.347 * *$ & $0.436 * * *$ & $0.302 *$ & $0.314 * *$ & $0.362 * * *$ & $0.340 * *$ & NS & $0.211^{*}$ & NS \\
\hline 2002 & $0.709 * * *$ & $0.715 * * *$ & $0.699 * * *$ & $0.608 * * *$ & $0.622 * * *$ & $0.582 * * *$ & $0.587 * * *$ & $0.602 * * *$ & $0.573 * * *$ \\
\hline 2003 & $0.348 * *$ & $0.415 * * *$ & $N S$ & $0.248^{*}$ & $0.270 * *$ & NS & NS & NS & NS \\
\hline 2004 & $0.498 * * *$ & $0.495 * * *$ & $0.512 * * *$ & NS & NS & NS & NS & NS & NS \\
\hline 2005 & $0.450 * * *$ & $0.519 * * *$ & $0.371 * *$ & $0.237^{*}$ & $0.321 * *$ & NS & $0.642 * * *$ & $0.669 * * *$ & $0.594 * * *$ \\
\hline 2006 & NS & NS & NS & $0.382 * * *$ & $0.415^{* * *}$ & $0.317^{*}$ & NS & NS & NS \\
\hline 2007 & & & & NS & $0.214^{*}$ & NS & & & \\
\hline 2008 & & & & $0.447 * * *$ & $0.469 * * *$ & $0.412 * * *$ & & & \\
\hline 2009 & $0.314 * *$ & $0.362 * * *$ & NS & $0.388 * * *$ & $0.419 * * *$ & $0.337 * *$ & $0.271^{*}$ & $0.315 * *$ & NS \\
\hline 1997-2009 & $0.303 * * *$ & $0.340 * * *$ & $0.305 * * *$ & $0.324 * * *$ & $0.308 * * *$ & $0.296 * * *$ & $0.287 * * *$ & $0.349 * * *$ & $0.295 * * *$ \\
\hline
\end{tabular}

$* P<0.05 * * P<0.01 * * * P<0.001, N S$ Non-significant 
Table 4 Multiple pairwise comparisons using Nemenyi's procedure between daily average Ambrosia pollen concentrations recorded in Rzeszów, Kraków and Poznań during 1997-2009

\begin{tabular}{|c|c|c|c|c|c|c|c|c|c|c|}
\hline \multirow[t]{2}{*}{ Year } & \multirow{2}{*}{$\begin{array}{l}\text { period } \\
\text { City }\end{array}$} & \multicolumn{3}{|l|}{ VIII-X } & \multicolumn{3}{|l|}{ VIII-15X } & \multicolumn{3}{|l|}{ VIII-IX } \\
\hline & & Rzeszów & Kraków & Poznań & Rzeszów & Kraków & Poznań & Rzeszów & Kraków & Poznań \\
\hline \multirow[t]{2}{*}{1997} & Rzeszów & & NS & NS & & NS & NS & & NS & NS \\
\hline & Kraków & NS & & NS & NS & & NS & NS & & NS \\
\hline \multirow[t]{2}{*}{1998} & Rzeszów & & $*$ & $*$ & & NS & $*$ & & NS & NS \\
\hline & Kraków & $*$ & & NS & NS & & NS & NS & & NS \\
\hline \multirow[t]{2}{*}{1999} & Rzeszów & & $*$ & NS & & $*$ & NS & & $*$ & NS \\
\hline & Kraków & * & & NS & * & & NS & * & & NS \\
\hline \multirow[t]{2}{*}{2000} & Rzeszów & & $*$ & NS & & $*$ & NS & & $*$ & NS \\
\hline & Kraków & $*$ & & NS & * & & NS & * & & NS \\
\hline \multirow[t]{2}{*}{2001} & Rzeszów & & NS & NS & & NS & $*$ & & NS & $*$ \\
\hline & Kraków & NS & & $*$ & NS & & * & NS & & * \\
\hline \multirow[t]{2}{*}{2002} & Rzeszów & & NS & * & & NS & * & & NS & $*$ \\
\hline & Kraków & NS & & * & NS & & * & NS & & * \\
\hline \multirow[t]{2}{*}{2003} & Rzeszów & & $*$ & NS & & $*$ & NS & & NS & $*$ \\
\hline & Kraków & $*$ & & $*$ & * & & $*$ & NS & & $*$ \\
\hline \multirow[t]{2}{*}{2004} & Rzeszów & & $*$ & NS & & $*$ & NS & & $*$ & NS \\
\hline & Kraków & $*$ & & $*$ & * & & $*$ & $*$ & & $*$ \\
\hline \multirow[t]{2}{*}{2005} & Rzeszów & & NS & NS & & NS & NS & & NS & $*$ \\
\hline & Kraków & NS & & NS & NS & & NS & NS & & NS \\
\hline \multirow[t]{2}{*}{2006} & Rzeszów & & NS & NS & & NS & NS & & NS & NS \\
\hline & Kraków & NS & & NS & NS & & NS & NS & & NS \\
\hline \multirow[t]{2}{*}{2009} & Rzeszów & & NS & NS & & NS & NS & & NS & NS \\
\hline & Kraków & NS & & NS & NS & & NS & NS & & NS \\
\hline
\end{tabular}

* $P<0.05$ (Bonferroni corrected significance level: 0.0167), NS non significant

slowly to the South and West. Ambrosia pollen counts at the three sites in Poland decreased on 7 and 8 September when air masses approached from a more southwesterly direction. Back-trajectory analysis shows that air masses approaching Rzeszów, Kraków and Poznań passed over eastern Poland and Ukraine on 4 and 5 September 1999 (Fig. 1a). The diurnal variations for the three sites (Fig. 1b) show that there was a night-time peak at Poznań between 2200 on 4 September and 0200 on 5 September (the highest bi-hourly concentration was 428 ragweed pollen grains $/ \mathrm{m}^{3}$ recorded at 0200 hours on 5 September). The plume can be tracked backwards as it passes over Kraków at around midafternoon (between 1400 and 1600 hours) and Rzeszów during mid-morning (highest bi-hourly concentration at
Rzeszów was 1,080 ragweed pollen grains $/ \mathrm{m}^{3}$ recorded at 1000 hours on 4 September 1999.

Back-trajectory analysis on the 3 September 2002

Ambrosia pollen concentrations at the sites examined in Poland from 1 to 2 September 2002 were generally low $\left(<10\right.$ grains $\left./ \mathrm{m}^{3}\right)$, except at Rzeszów where daily average Ambrosia pollen counts $>20$ grains $/ \mathrm{m}^{3}$ were recorded on 1 September 2002. Daily average Ambrosia pollen counts approaching or $>20$ grains $/ \mathrm{m}^{3}$ were recorded at Rzeszów from 3 to 6 September, at Poznań from 3 to 5 September, and at Kraków on 4 September (Table 7). The synoptic situation in this period was characterised by a series of low-
Table 5 Spearman rank correlation test and Nemenyi's procedure applied to total annual Ambrosia pollen counts (SPI) recorded in Rzeszów, Kraków and Poznań during 1997-2009

${ }^{*} P<0.05, N S$ non significant

\begin{tabular}{|c|c|c|c|c|c|c|}
\hline & \multicolumn{3}{|c|}{ Spearman correlation test } & \multicolumn{3}{|c|}{ Nemenyi's procedure } \\
\hline & Rzeszów & Kraków & Poznań & Rzeszów & Kraków & Poznań \\
\hline Rzeszów & & 0.127 & 0.246 & & * & $*$ \\
\hline Kraków & & & 0.110 & & & NS \\
\hline Poznań & & & & & & \\
\hline
\end{tabular}


Table 6 Trends in total annual Ambrosia pollen counts (SPI) recorded in Rzeszów, Kraków and Poznań during 1997-2009

\begin{tabular}{lrrr}
\hline & \multicolumn{2}{l}{ SPI } & \\
\cline { 2 - 4 } & Rzeszów & Kraków & Poznań \\
\hline Mean & 378.0 & 170.5 & 126.5 \\
SD & 212.6 & 122.0 & 109.5 \\
CV(\%) & 56.3 & 71.6 & 86.5 \\
slope & -19.0 & 12.0 & -7.5 \\
SE & 18.3 & 8.7 & 8.2 \\
$R^{2}$ & 0.1 & 0.1 & 0.1 \\
$P$ & 0.3 & 0.2 & 0.4 \\
\hline
\end{tabular}

pressure systems $(\sim 965-986 \mathrm{hPa})$ that passed to the north of the British Isles on their passage from the North Atlantic toward Svalbard (North of mainland Scandinavia) and Arctic Russia. Corresponding high-pressure areas were located in the vicinity of Continental Europe $(\sim 1,017-$ $1,032 \mathrm{hPa}$ ). In the morning of 1 September 2002, air masses approached the pollen-monitoring sites from a southerly direction before veering to the north later in the day. The air masses continued to veer throughout the episode, first approaching from the North to Northeast (2 September), then from the Northeast to South (3-5 September) and finally from the South to West (6-7 September). Backtrajectory analysis shows that possible sources of Ambrosia pollen on 3 September 2002 included eastern Poland and Ukraine (Fig. 2a). The highest bi-hourly ragweed pollen concentration recorded at Poznań on 3 September 2002 was 134 grains $/ \mathrm{m}^{3}$ at 1600 hours (Fig. 2b). Similar to the episode on 4 and 5 September 1999, the plume of Ambrosia pollen can be followed as it passed Kraków and Rzeszów. The peak is not as noticeable at Kraków; there was a small peak of 33 grains $/ \mathrm{m}^{3}$ at 1400 hours, which followed a larger peak of 58 grains $/ \mathrm{m}^{3}$ at 0600 hours. However, there was a larger bi-hourly peak of 130 ragweed pollen grains/ $\mathrm{m}^{3}$ recorded at Rzeszów at 1000 hours on 3 September 2002 .

\section{Discussion}

The ability of Ambrosia pollen grains to be transported long distances means that ragweed pollen from regions with abundant sources of Ambrosia can be responsible for high ragweed pollen concentrations in areas where the source plant is scarce or not even registered (Šikoparija et al. 2009). In areas considered to be centres of ragweed pollen production, such as France and Hungary, ragweed pollen is the most frequent cause of allergy symptoms during late summer. In Poland, where most ragweed pollen is considered to be allochthonous, studies have shown that $42 \%$ of patients suffering from pollen allergy did not show symptoms of allergy during the Ambrosia pollen season although they were sensitised to Ambrosia allergens (Obtułowicz et al. 1995).

In order treatment to be effective, allergy patients need to be able to plan their medication in advance (Stern et al. 1997; Sabbah et al. 1999; Bousquet et al. 2001). This planning requires knowledge of atmospheric pollen concentrations several days before, and so reliable pollen forecasts are needed. Information about possible sources of pollen, including long-distance transport, would increase the accuracy of such forecasts (Skjøth et al. 2008). A number of studies, using a combination of Ambrosia pollen data and air mass trajectories, have contributed to the knowledge of potential source areas of ragweed in Central Europe and conditions that lead to regional scale or longdistance transport episodes (Cecchi et al. 2006, 2007; Stach et al. 2007; Smith et al. 2008; Śikoparija et al. 2009). The eventual aim of this work is to produce a numerical forecast for Ambrosia pollen.

An operational dispersion model for Ambrosia pollen would require several components, including an emission inventory and a phenological model capable of predicting flowering in the source area. Emission inventories of sources are rarely available for pollen (Skjøth et al. 2010), but when applied by a transport model the inventory can be used for analysing conditions needed for the long-distance

Table 7 Daily average Ambrosia pollen counts (grains $/ \mathrm{m}^{3}$ ) recorded at the three sites included in this study on 1-8 September 1999 and 1-8 September 2002

\begin{tabular}{lccc}
\hline & Rzeszów & Kraków & Poznań \\
\hline 1 September 1999 & 1 & 0 & 0 \\
2 September 1999 & 6 & 0 & 0 \\
3 September 1999 & 101 & 86 & 15 \\
4 September 1999 & 319 & 66 & 97 \\
5 September 1999 & 80 & 42 & 109 \\
6 September 1999 & 88 & 71 & 70 \\
7 September 1999 & 30 & 26 & 15 \\
8 September 1999 & 7 & 0 & 0 \\
1 September 2002 & 60 & 8 & 2 \\
2 September 2002 & 0 & 6 & 0 \\
3 September 2002 & 36 & 17 & 38 \\
4 September 2002 & 84 & 39 & 32 \\
5 September 2002 & 98 & 10 & 37 \\
6 September 2002 & 40 & 5 & 1 \\
7 September 2002 & 12 & 3 & 0 \\
8 September 2002 & 9 & 5 & 0 \\
\hline
\end{tabular}


Fig. 1 a Back-trajectory analysis for 4 and 5 September 1999 calculated at Rzeszów, Kraków and Poznań. b Bi-hourly Ambrosia pollen counts recorded at the three sites during the same period (a)
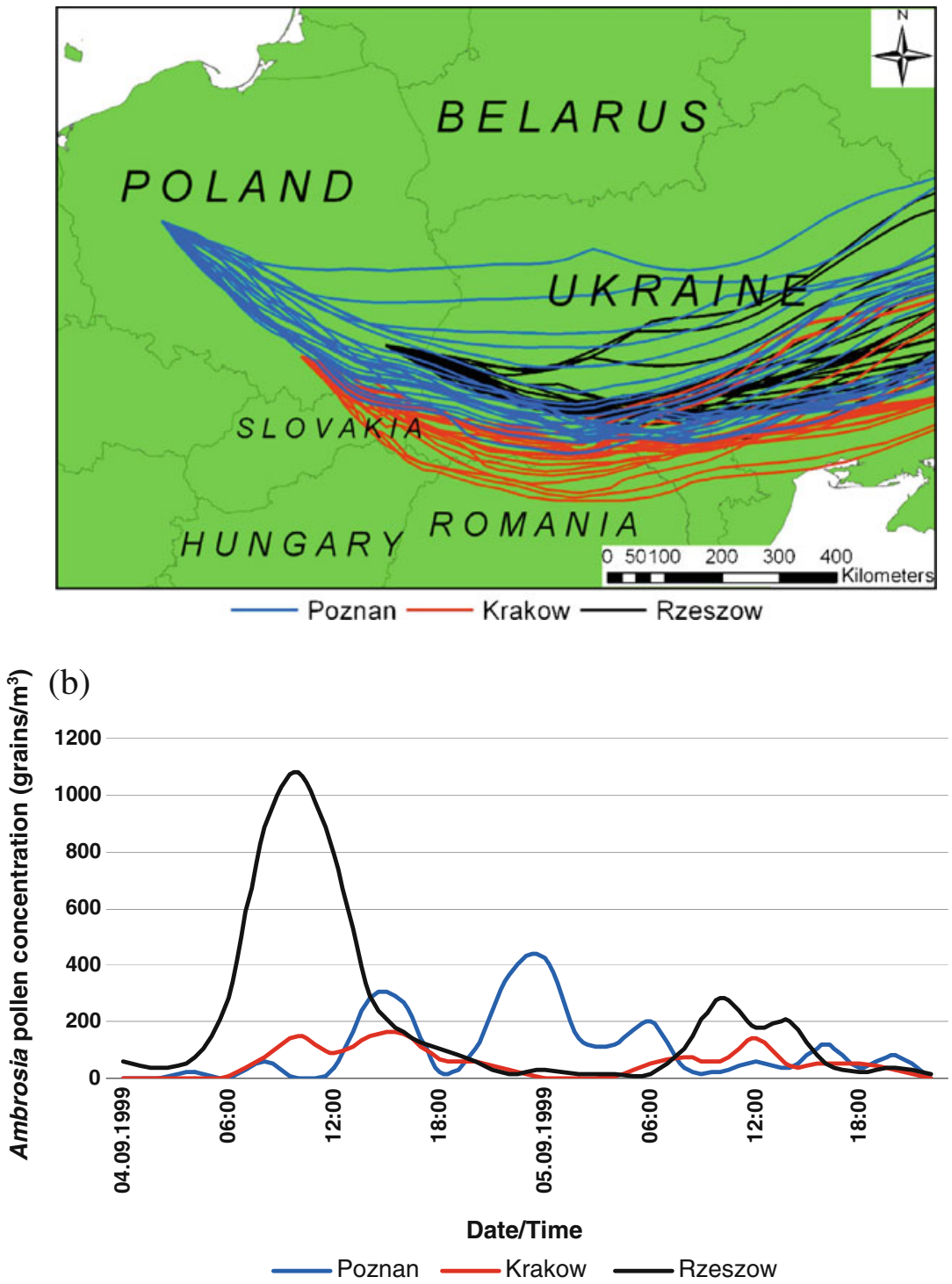

transport of ragweed pollen (Šikoparija et al. 2009). Backtrajectories can therefore be used to discover sources of ragweed pollen for the inventory, as well as to identify specific episodes that can be used to calibrate the dispersion model. However, source-based dispersion models cannot be used unless the main source regions are adequately described. This is of high priority as emission inventories are generally considered to be among the biggest uncertainties in atmospheric transport models (Russell and Dennis 2000). As a result, studies that identify main source regions such as this one are important.

This study revealed that the amount of ragweed pollen in Rzeszów was significantly higher than in Poznań and Kraków. This can be related to both the higher abundance of local populations of Ambrosia in south-east Poland and the proximity of Rzeszów to foreign sources of ragweed pollen. The intermittent character of ragweed pollen in Poland is expressed by the high variability of annual pollen sums and the lack of distinctly marked trends. Due to the scattered distribution of ragweed populations in Poland, the occurrence of Ambrosia pollen relies mainly on conditions being appropriate for long-range transport (Stach et al. 2007; Smith et al. 2008).

The results of statistical analysis show that there were three years (1999, 2002 and 2005) when a combination of significant correlations between daily average Ambrosia pollen counts, and daily average Ambrosia pollen counts $>20$ grains $/ \mathrm{m}^{3}$ was recorded at all three sites (Tables 2, 3). This suggests that high concentrations of pollen grains occurred in the air of Rzeszów, Kraków and Poznań almost at the same time. It is likely that 
Fig. 2 a Back-trajectory analysis for 3 September 2002 calculated at Rzeszów, Kraków and Poznań. b Bi-hourly Ambrosia pollen counts recorded at the three sites during the same period (a)

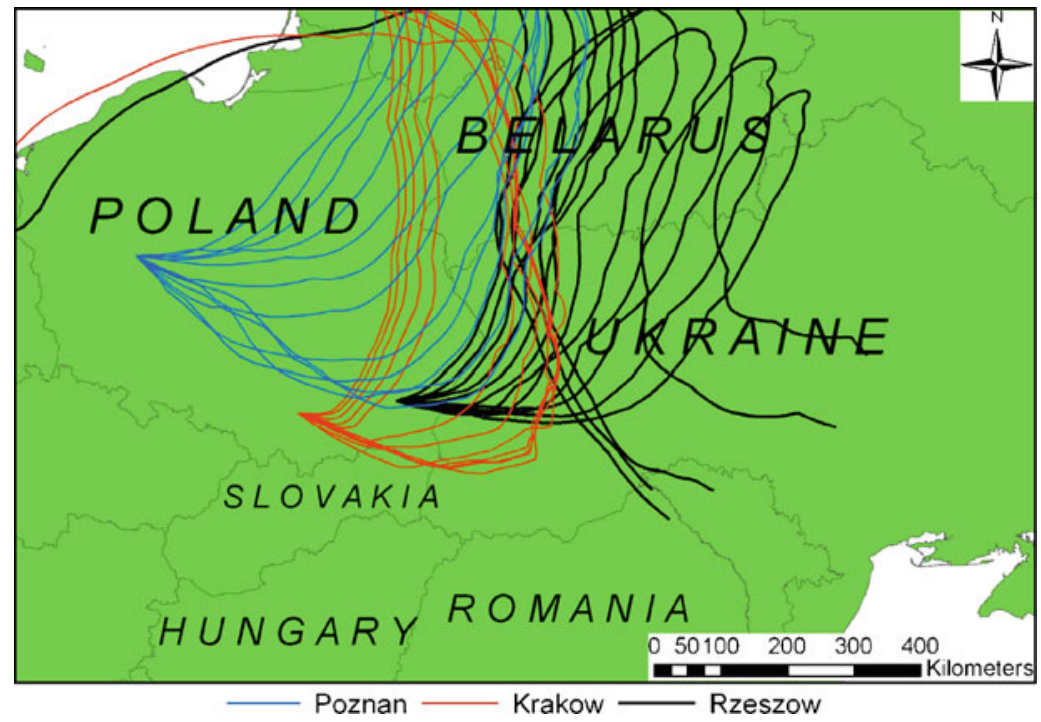

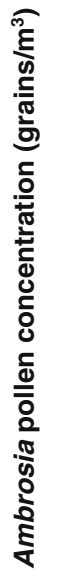
(b)

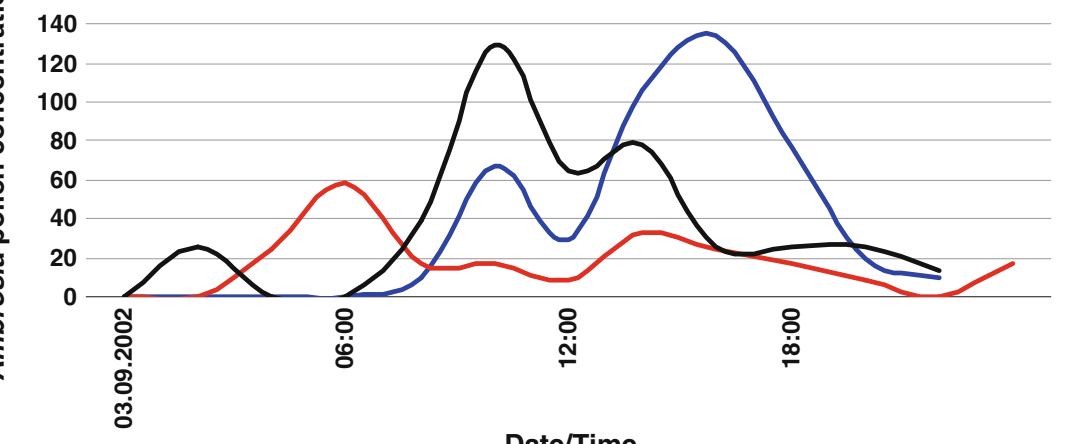

Date/Time

- Poznan Krakow Rzeszow

this synchronisation of pollen seasons in different places was caused by transport of pollen from distant sources.

The Ambrosia pollen episode that occurred in 2005 has been well documented (Stach et al. 2007; Smith et al. 2008) and showed that air masses arrived in Poland predominantly from the Czech Republic, Slovakia and Hungary, passing mountain areas via the Morawy Gate and Low Beskid passes, identifying these countries as potential source areas. In this study, the combined results of pollen measurements and air mass trajectory calculations identified plumes of Ambrosia pollen that were recorded at Rzeszów, Kraków and Poznań on 4 and 5 September 1999 and 3 September 2002. These plumes arrived at the pollen-monitoring sites from an easterly direction and indicated that sources of Ambrosia pollen were present in either eastern Poland, in the region around Rzeszów, or Ukraine
Kasprzyk (2008) also evaluated the effect of weather conditions on daily Ambrosia pollen concentrations in Rzeszów from 3 to 5 September 1999. The author noted that the prevailing wind was from an East-North-East (3 September) or East-South-East (4 and 5 September) direction, and that the greatest number of pollen grains was recorded during the day, at about noon. This led the author to suggest that a midday maximum may indicate that the sources of pollen were not as far away as was previously supposed (Kasprzyk 2008). The results of the current study support this view, as the noon peak in ragweed pollen concentrations registered in Rzeszów during both episodes indicates that the pollen brought to Poland originated either from local Polish populations or Ukrainian populations situated close to the Polish border. In addition, it should be noted that ragweed pollen arriving at the Polish sites included 
in this study could have travelled for a long time, even from regions situated further to the East (Fig. 1) and North (Fig. 2) in Ukraine. Such regional scale transport could augment ragweed pollen emitted from local sources around Rzeszów.

Back-trajectories calculated at the time of peak Ambrosia pollen concentration on 3 September 2002 at Poznań are similar to those presented by Stach et al. (2007). In this latter study, the authors described how the air masses passed over eastern Poland after traversing parts of Russia and Lithuania (Stach et al. 2007). However, back-trajectories calculated for Kraków and Rzeszów suggested that the Ambrosia pollen may have originated from territory further east. One reason for this contradiction might be related to the amount of uncertainty involved in calculating the path taken by a parcel of air. For example, the path of a single trajectory will differ depending on the release height of the parcel in the atmosphere. Furthermore, trajectory models are, in general, very sensitive to the quality and resolution of input data. It has been shown that changing input data from $150 \mathrm{~km}$ grid resolution and 6-h temporal resolution to $39 \mathrm{~km}$ grid resolution and 1-h temporal resolution, increased the accuracy significantly (Skjøth et al. 2002). As such, a single trajectory can be very uncertain, depending on the input data and the choice of the calculation method. One way of estimating the uncertainty of the trajectories is to use a matrix of several trajectories for single episodes, where trajectories start at different locations at some distance to each other. The spread between the trajectories is then an indicator of the accuracy of the reference trajectory. This trajectory matrix has been employed as a standard methodology for a number of studies (Smith et al. 2005, 2008; Skjøth et al. 2007, 2008; Stach et al. 2007), and in 2010 was adapted as a standard methodology in the on-line version of the HYSPLIT trajectory model (Draxler and Rolph 2010).

Two examples of regional scale transport are presented in this paper. If the plumes of Ambrosia pollen tracked on 4 and 5 September 1999 and 3 September 2002 did not originate from inside Poland, then it is likely that they came from Ukraine, where Ambrosia psilostachya, A. artemisiifolia and A. trifida occur in nearly all of the country (Mosyakin and Yavorska 2002; Protopopova et al. 2003; Grygorak et al. 2004). The total area of ragweed distribution in Ukraine now exceeds $10,000 \mathrm{~km}^{2}$ and is still increasing (Reznik 2009). This identifies a possible new source of ragweed pollen for Poland as well as other European countries. Bearing in mind the fact that winds in the studied region are predominantly from the west and that studies have shown that the most ragweed pollen is transported from eastern and southern directions into Poland (Stach et al. 2007; Smith et al. 2008), we can suggest that western parts of Poland could be considered free of abundant ragweed populations and that the most potent sources of ragweed pollen recorded in Poland are situated in Ukraine and the Pannonian Plain.
Acknowledgements The authors would like to thank the National Centre for Environmental Prediction (NCEP) for providing input data to the Eta model and for providing verifying meteorological observations exchanged under the World Meteorological Organization (WMO) World Weather Watch Programme. This work was partly funded by the Copenhagen Global Change Initiative (http://www. cogci.dk) and by the Ministry of Science R. Serbia project no. 143037. The work was also partly funded by COST Action ES0603 (EUPOL) (http://www.cost.esf.org/index.php?id=1080) through Short Term Scientific Mission, reference code: COST-STSM-ES0603-03990. The results presented here address one of the main scientific challenges described in COST Action ES0603, specifically Work Package 1 (pollen production and release) and Work Package 2 (pollen atmospheric distribution and interaction).

Open Access This article is distributed under the terms of the Creative Commons Attribution Noncommercial License which permits any noncommercial use, distribution, and reproduction in any medium, provided the original author(s) and source are credited.

\section{References}

Allard HA (1945) Flowering behaviour and natural distribution of the eastern ragweeds (Ambrosia) as affected by length of day. Ecology 26(4):387-394

Asero R, Wopfner N, Gruber P, Gadermaier G, Ferreira F (2006) Artemisia and Ambrosia hypersensitivity: co-sensitization or corecognition? Clin Exp Allergy 36:658-665

Bianchi DE, Schwemmin DJ, Wagner WH Jr (1959) Pollen release in the common ragweed (Ambrosia artemisiifolia). Bot Gaz 120 (4):235-243

Bousquet J, Van Cauwenberge P, Khaltaev N, Ait-Khaled N, AnnesiMaesano I, Baena-Cagnani C, Bateman E, Bonini S, Canonica GW, Carlsen KH, Demoly P, Durham SR, Enarson D, Fokkens WJ, van Wijk RG, Howarth P, Ivanova NA, Kemp JP, Klossek JM, Lockey RF, Lund V, Mackay I, Malling HJ, Meltzer EO, Mygind N, Okunda M, Pawankar R, Price D, Scadding GK, Simons FER, Szczeklik A, Valovirta E, Vignola AM, Wang DY, Warner JO, Weiss KB (2001) Allergic rhinitis and its impact on asthma. J Allergy Clin Immunol 108:S147-S334

Brandes D, Nietzsche J (2006) Biology, introduction, dispersal, and distribution of common ragweed (Ambrosia artemisiifolia L.) with special regard to Germany. Nachrichtenbl Deut Pflanzenschutzd 58(11):286-291

Brzeźniak E (2007) Tendencje zmian opadów atmosferycznych w Karpackim Wschodnim regionie opadowym [Tendency in precipitation change in the East Carpathian rainfall region]. Problemy Zagospodarowania Ziem Górskich 54:71-81

Cecchi L, Morabito M, Domeneghetti MP, Crisci A, Onorari M, Orlandini S (2006) Long distance transport of ragweed pollen as a potential cause of allergy in central Italy. Ann Allergy Asthma Immunol 96(1):86-91

Cecchi L, Torrigiani Malaspina T, Albertini R, Zanca M, Ridolo E, Usberti I, Morabito M, Dall' Aglio P, Orlandini S (2007) The contribution of long-distance transport to the presence of Ambrosia pollen in central northern Italy. Aerobiologia 23:145-151

Chłopek K, Dąbrowska K (2006) Pyłek wybranych taksonów roslin w powietrzu Poznania, 2001-2005. In: E WeryszkoChmielewska (ed) Pyłek roślin w aeroplanktonie różnych regionów Polski. Wyd. Katedry i Zakładu Farmakognozji Wydziału Farmaceutycznego AM w Lublinie, Lublin, pp 31-47

Chłopek K, Tokarska-Guzik B (2006) Pyłek ambrozji (Ambrosia) w aeroplanktonie Górnego Ślaska. [Ragweed (Ambrosia) pollen in aeroplankton of Upper Silesia]. Acta Agrobot 59(1):335-345 
Chrenová J, Mičieta K, Ščevkovă J (2009) Monitoring of Ambrosia pollen concentration in the atmosphere of Bratislava (Slovakia) during years 2002-2007. Aerobiologia. doi:10.1007/s10453-009-9145-3

Comtois P (1998) Ragweed (Ambrosia sp.): the Phoenix of allergophytes. 6th International Congress on Aerobiology. Satellite Symposium Proceedings: Ragweed in Europe, Perugia, Italy, ALK Abelló

Dahl A, Strandhede S-O, Wihl J-A (1999) Ragweed—an allergy risk in Sweden? Aerobiologia 15(4):293-297

de Visiani R (1842) Flora Dalmatica. Hofmeister, Leipzig

Draxler RR, Rolph GD (2010) HYSPLIT (HYbrid Single-Particle Lagrangian Integrated Trajectory) Model access via NOAA ARL READY Website (http://ready.arl.noaa.gov/HYSPLIT.php), NOAA Air Resources Laboratory, Silver Spring, MD

Emberlin J (2000) Aerobiology. In: WW Busse, ST Holgate (eds) Asthma and rhinitis, vol 2. Blackwell, Oxford

Faegri K, Iversen J (1992) Textbook of pollen analysis. Wiley, New York

Fumanal B, Chauvel B, Bretagnolle F (2007) Estimation of pollen and seed production of common ragweed in France. Ann Agric Environ Med 14:233-236

Galán C, Cariñanos P, Alcázar P, Dominguez-Vilches E (2007) Spanish Aerobiology Network (REA) Management and quality manual, Servicio de Publicaciones Universidad de Córdoba. ISBN 978-84-690-6353-8

Genton BJ, Shykoff JA, Giraud T (2005) High genetic diversity in French invasive populations of common ragweed, Ambrosia artemisiifolia, as a result of multiple sources of introduction. Mol Ecol 14:4275-4285

Grygorak MY, Protopopova VV, Shevera MV (2004) Aspekty economicznoi ocinky vplyvu neaborygenych Roslyn Ukrainy na dovkillya. [Aspects of economical evaluation of environmental influence of non-aboriginal plants in Ukraine]. Regionalny perspectyvy [Regional perspective] 6:44-48

Hirst JM (1952) An automatic volumetric spore trap. Ann Appl Biol 39(2):257-265

Jackowiak B (1993) Atlas of Distribution of Vascular plants in Poznan, Poznan. Publications of the Department of Plant Taxonomy of Adam Mickiewicz University, No 2

Jäger S (2000) Ragweed (Ambrosia) sensitisation rates correlate with the amount of inhaled airborne pollen. A 14-year study in Vienna, Austria. Aerobiologia 16(1):149-153

Járai-Komlódi M (2000) Some details about ragweed airborne pollen in Hungary. Aerobiologia 16(2):291-294

Juhász M, Gallowich E (1995) Comparative aeropalynological study of ragweed pollution in Szeged and Pécs (Southern Hungary). In: Schweiger O, Szabó T (eds) Environmental damages and the respiratory system, vol 5. Szentmihályi, Zalaegerszeg, p 244

Juhász M, Juhász I, Gallovich R, Radisic P, Ianovici N, Peternel R, KofolSeliger A (2004) Last years ragweed pollen concentrations in the Southern part of Carpathian Basin. Proceedings: 11th Symposium on Analytical and Environmental Problems, Szeged, Hungary

Kasprzyk I (2008) Non-native Ambrosia pollen in the atmosphere of Rzeszów (SE Poland); evaluation of the effect of weather conditions on daily concentrations and starting dates of the pollen season. Int J Biometeorol 52(5):341-351

Laaidi K, Laaidi M (1999) Airborne pollen of Ambrosia in Burgundy (France) 1996-1997. Aerobiologia 15(1):65-69

Laaidi M, Thibaudon M, Besancenot J-P (2003) Two statistical approaches to forecasting the start and duration of the pollen season of Ambrosia in the area of Lyon (France). Int $\mathrm{J}$ Biometeorol 48(2):65-73

Makovcová S, Zlinská J, Mikolás V, Salát D, Krio M (1998) Ragweed in Slovak Republic. 6th International Congress on Aerobiology. Satellite Symposium Proceedings: Ragweed in Europe, Perugia, Italy, ALK Abelló
Makra L, Juhász M, Béczi R, Borsos E (2005) The history and impacts of airborne Ambrosia (Asteraceae) pollen in Hungary. Grana 44:57-64

Matuszko D (ed) (2007) Klimat Krakowa w XX wieku (Climate of Kraków in the twentieth century). Institute of Geography and Spatial Management, Kraków

Mosyakin SL, Yavorska OG (2002) The Nonnative Flora of the Kyiv (Kiev) urban area, Ukraine: a checklist and brief analysis. Urban Habitats 1(1):45-65

Niedźwiedź T (1981) Sytuacje synoptyczne i ich wpływ na zróżnicowanie przestrzenne wybranych elementów klimatu w dorzeczu górnej Wisły. [Synoptic situations and their influence on spatial differentiation of chosen elements of climate of the upper Wisła Basin] Uniwersytet Jagielloński, Kraków

Niedźwiedź T (2004) Kalendarz sytuacji synoptycznych dla dorzecza górnej Wisły (1997-2004); plik komputerowy dostępny w Katedrze Klimatologii, Wydział Nauk o Ziemi Uniwersytetu Śląskiego, Sosnowiec [Calendar of synoptic situations for Upper Wisła Basin; computer packet available in Climatology Departament, Earth Science Faculty, Śląsk University, Sosnowiec]

Niedźwiedź T, Obrębska-Starklowa B (1991) Klimat. (Climate). In: Dynowska I, Maciejewski M (eds) Dorzecze Górnej Wisły (Upper Vistula Basin). PWN, Warszawa-Kraków, pp 69-84

Nobis M, Nobis A (2006) Interesujące, rzadkie i rozprzestrzeniające się gatunki roślin naczyniowych notowane na terenach kolejowych w południowo-wschodniej Polski. [Some interesting, rare and spreading species of vascular plants noted on railway-tracks in the south-eastern Poland]. Fragmnt Flor Geobot Pol 13(2):301-308

Obtułowicz K, Szczepanek K, Myszkowska D (1995) Ambrosia pollen grains in aeroplankton of Krakow and their role in pollen allergy of this region. In: Spiewak R (ed) Pollens and pollinosis: current problems. Institute of Agricultural Medicine, Lublin, p 56

Ogden EC, Hayes JV, Raynor GS (1969) Diurnal patterns of pollen emission in Ambrosia, Phleum, Zea and Ricinus. Am J Bot 56 (1): $16-21$

Peternel R, Culig J, Srnec L, Mitic B, Vukusic I, Hrga I (2005) Variation in ragweed (Ambrosia artemisiifolia L.) pollen concentration in Central Croatia. Ann Agric Environ Med 12(1):11-16

Piotrowska K, Weryszko-Chmielewska E (2006) Ambrosia pollen in the air of Lublin, Poland. Aerobiologia 2006(22):151-158

Protopopova VV, Mosyakin SL, Shevera MV (2003) Vplyv neaborygennych vysiv roslyn na biotu Ukrainy [Influence of nonaboriginal types of plants on the biotype of Ukraine]. In: O Dudkin (ed.) Odcinka i napryamky zagroz biorisnomanittyu [Evaluation and directions of biological versatility]. Khimdzest, pp $129-155$

Reznik S (2009) Common ragweed (Ambrosia artemisiifolia L.) in Russia: spread, distribution, abundance, harmfulness and control measures, Ambroisie. The first international ragweed review, AFEDA, pp 88-97

Russell A, Dennis R (2000) NARSTO critical review of photochemical models and modeling. Atmos Environ 34:2283-2324

Rybníček O, Novotná B, Rybníckova E, Rybnícek K (2000) Ragweed in the Czech Republic. Aerobiologia 16(2):287-290

Saar M, Gudžinskas Z, Plompuu T, Linno E, Minkiene Z, Motiekaityte V (2000) Ragweed plants and airborne pollen in the Baltic States. Aerobiologia 16(1):101-106

Sabbah A, Daele J, Wade AG, Ben Soussen P, Attali P (1999) Comparison of the efficacy, safety, and onset of action of mizolastine, cetirizine, and placebo in the management of seasonal allergic rhinoconjunctivitis. Ann Allergy Asthma Immunol 83:319-25

Šikoparija B, Radišić P, Pejak T, Šimić S (2006) Airborne grass and ragweed pollen in the southern Panonnian Valley-consideration of rural and urban environment. Ann Agric Environ Med $13: 263-266$ 
Šikoparija B, Smith M, Skjøth CA, Radišić P, Milkovska S, Šimić S, Brandt J (2009) The Pannonian Plain as a source of Ambrosia pollen in the Balkans. Int J Biometeorol 53:263-272

Skjøth AC, Hertel O, Ellermann T (2002) Use of the ACDEP trajectory model in the Danish nation-wide Background Monitoring Programme. Phys Chem Earth Pt B 27(35):1469-1477

Skjøth CA, Sommer J, Stach A, Smith M, Brandt J (2007) The long range transport of birch (Betula) pollen from Poland and Germany causes significant pre-season concentrations in Denmark. Clin Exp Allergy 37:1204-1212

Skjøth CA, Smith M, Brandt J, Emberlin J (2008) Are the birch trees in Southern England a source of Betula pollen for North London? Int J Biometeorol 53:75-86

Skjøth CA, Smith M, Šikoparija B, Stach A, Myszkowska D, Kasprzyk I, Radisic P, Stjepanovic B, Hrga I, Apatini D, Magyar D, Páldy A, Ianovici N (2010) A method for producing airborne pollen source inventories: An example of Ambrosia (ragweed) on the Pannonian Plain. Agric and Forest Meteorol 150:1203-1210. doi:10.1016/j.agrformet.2010.05.002.

Smith M, Emberlin J, Kress A (2005) Examining high magnitude grass pollen episodes at Worcester, United Kingdom, using backtrajectory analysis. Aerobiologia 21(2):85-94

Smith M, Skjøth CA, Myszkowska D, Uruska A, Malgorzata P, Stach A, Balwierz Z, Chlopek K, Piotrowska K, Kasprzyk I, Brandt J (2008) Long-range transport of Ambrosia pollen to Poland. Agric For Meteorol 148(10):1402-1411

Stach A (2000) Variation in pollen concentration of the most allergenic taxa in Poznan (Poland), 1995-1996. Aerobiologia 16:63-68

Stach A (2006) Is pollen of ragweed (Ambrosia spp.) a threat to people with allergies in the Wielkopolska region? Biodivers Res Conserv 3-4:320-323

Stach A, Smith M, Skjøth CA, Brandt J (2007) Examining Ambrosia pollen episodes at Poznan (Poland) using back-trajectory analysis. Int J Biometeorol 51:275-286
Stępalska D, Szczepanek K, Myszkowska D (2002) Variation in Ambrosia pollen concentration in Southern and Central Poland in 1982-1999. Aerobiologia 18(1):13-22

Stępalska D, Myszkowska D, Wołek J, Piotrowicz K, Obtułowicz K (2008) The influence of meteorological factors on Ambrosia pollen loads in Cracow, Poland, 1995-2006. Grana 47(4):297304

Stern MA, Darnell R, Tudor D (1997) Can an antihistamine delay appearance of hay fever symptoms when given prior to pollen season? Allergy 52:440-444

Taramaracaz P, Lambelet C, Clot B, Keimer C, Hauser C (2005) Ragweed (Ambrosia) progression and its health risks: will Switzerland resist this invasion? Swiss Med Wkly 135:538-548

Tokarska-Guzik B (2001) Ambrosia artemisiifolia L. i Ambrosia psilostachya DC. In: Zając A, Zając M (eds) Atlas rozmieszczenia roślin naczyniowych $\mathrm{w}$ Polsce. Pracownia Chronologii Komputerowej [Distribution Atlas of vascular Plants in Poland], Instytut Botaniki Uniwersytetu Jagiellońskiego, Kraków [Laboratory of Computer Chorology, Institute of Botany, Jagiellonian University, Kraków], pp 55

Vitányi L, Makra L, Juhász M, Borsos E, Béczi R, Szentpéteri M (2003) Ragweed pollen concentration in the function of meteorological elements in the south-eastern part of Hungary. Acta Climatol Chorolog Univ Szegediensis t 36-37:121-130

Woś A (1994) Klimat Niziny Wielkopolskiej. Adam Mickiewicz University, Poznan

XLSTAT (2010) Statistical software-help document: nonparametric tests. Comparison of $\mathrm{k}$ samples (Kruskal-Wallis, Friedman). Description. Addinsoft, http://www.xlstat.com/

Yankova R, Zlatev V, Baltadjieva D, Mustakov T, Mustakov B (2000) Quantitative dynamics of Ambrosia pollen grains in Bulgaria. Aerobiologia 16(2):299-301

Żukowski W (1960) Kilka interesujacych gatunków synantropijnych z miasta Poznania. Przyr Pol Zach 4:141-145 